\title{
Want to make me emotional? The influence of emotional advertisements on women's consumption behavior
}

\author{
Salman Majeed ${ }^{1 *}$, Changbao Lu² and Muhammad Usman ${ }^{3,4}$
}

\author{
* Correspondence: salmanphd@ \\ hotmail.com \\ ${ }^{1}$ School of Economics and \\ Management, Fuzhou University, \\ Fuzhou, Fujian 350002, People's \\ Republic of China \\ Full list of author information is \\ available at the end of the article
}

\begin{abstract}
A wide difference of opinion exists about the content and composition of emotions. Advertising may influence an audience and their buying decisions about products and services. The objective of this study is to better conceptualize how women emotionally respond to emotional advertisements (EAs). The variant views are integrated into an ACE model, composed of subordinate levels of emotions (E), celebrity endorsements (C), and appeal drivers (A). This empirical study examines women's emotional response using data from 240 Chinese women respondents. The study participants were invited to develop ACE mix based advertisements and fill out questionnaires. PLS-SEM analysis, a novel approach in ACE advertisement

development and its applicability to consumer behavior, was used. The results show that showbiz celebrities expressing the emotion of happiness with music and color make the most effective ACE mix to influence the consumption behavior of women. The results are significantly mediated by attention levels and are widely applicable in the burgeoning advertising industry. The study also calls for further research with different ACE mixes in different contexts and on different audiences. It also opens doors for policy making and an appropriate understanding of women's consumption behavior in the Chinese context.

Keywords: Emotions, Celebrity endorsement, Appeal drivers, Advertisement, Consumer behavior
\end{abstract}

\section{Introduction}

Advertising is an old phenomenon, which has been evolved over centuries. Multidimensional tactics, which are being incorporated in advertisements to influence consumer behavior, have ushered the advertisement industry into a new era. Since emotions shape consumers' behavior and decision-making (Khuong and Tram, 2015; Sebastian, 2014), anecdotal shreds of evidence suggest that emotional advertisement (EA) has become a strategic tool to influence consumer behavior favorably in a diversified business world. Advertisers deploy creative strategies, for example, incorporating emotions into advertisements in order to play on consumers' heartstrings with the intention of influencing their decision-making (Roozen, 2013). The oft-quoted emotional descriptions link emotions (E) to gestures, postures, and tactics to manage actions or reactions (Bagozzi et al., 1999; Hakkak

(c) The Author(s). 2019 Open Access This article is distributed under the terms of the Creative Commons Attribution 4.0 International License (http://creativecommons.org/licenses/by/4.0/), which permits unrestricted use, distribution, and reproduction in any medium, provided you give appropriate credit to the original author(s) and the source, provide a link to the Creative Commons license, and indicate if changes were made. 
et al., 2016; King, 2016 Rhoton, 2014). Emotions are generally perceived to be categorized in the obvious conceptualized dimensions, for example, negative emotions (shame, disgust, fear, sadness, anger, rage, revenge, disappointment, etc.) and positive emotions (joy, love, pride, happiness, hope, etc.) (Hakkak et al., 2016; Plutchik, 1997; Ekman, 2007; Bindu et al., 2007), but there is more emotional context hidden beneath this simple demarcation. Many researchers see the need to study specific emotional states in greater detail. This is the reason that in the marketing context emotional appeals and their incorporation into promotions were rated as firms' most important tools for successful marketing strategies (Roos, 2014).

Every consumer has different choice criteria for advertised products (a term used to address both products and services). Consumers evaluate products with their unique choice and attention criteria which may include perceptions about the products and different appeal drivers (A), that is, the product's characteristics: how the product sounds, looks, feels, etc. (O' Shaughnessy and O' Shaughnessy, 2003; Randhir et al., 2016; Wagner, 2013). For example, a food advertisement incorporating the sound of a sizzling steak, or a soft drink advertisement incorporating the sound of a soda cane opening, with soda coming out, may strongly affect consumers making them crave the product to satisfy their hunger and thirst (Lewis et al., 2012). Hence, marketers attempt to stimulate consumers with emotions and a wide variety of appeal drivers in order to influence consumers to choose their product. In doing so, many celebrities (C) often appear in marketing and promotional communication (Patel, 2009). For example, featuring of David Beckham, an English soccer star, in Police sunglasses and Vodafone advertisements was associated with an unprecedented increase in the business of the respective companies (Pringle, 2004). One of the strategic tools of modern day marketing is the celebrity endorsement (Biswas et al., 2009). It is estimated that about $20-30 \%$ of advertisements generally feature celebrity endorsers (Sliburyte, 2009; Hambrick and Mahoney, 2011), and this trend has increased considerably in recent decades. Although marketing professionals and other stakeholders are convinced about the effectiveness of celebrity endorsers, yet little is known about what kind of celebrity endorsement is a good fit with EAs, under emotions and appeal drivers, to influence consumers' attention, buying and consumption behavior (Erdogan et al., 2001; Agrawal and Kamakura, 1995). The academic literature on marketing varies widely in addressing this dilemma.

Further, it demands investment and effort from companies to lead the market unless they invest in EAs appropriately. Consequently, billions of dollars are invested every year in marketing and advertisement strategies with the intention of influencing the behavior of consumers. However, much of the invested effort and money is wasted on poor marketing ploys which quickly exhaust opportunities to convince consumers to buy their products. There might be many reasons for this failure, which range from the improper combination of emotions (E), celebrity endorsements $(\mathrm{C})$ and supporting appeal drivers $(\mathrm{A})$ in the advertisements. Apart from the industry perspective, the right choice of audience and their gender can determine the success magnitude of the EAs, which ultimately turns into market share maximization. Further, it has been documented that men and women may have different emotional responses towards advertised products, which may impact their attention and consumption patterns. This may further impact the success or failure of the advertised product (Donges et al., 2012; Vigil, 2009; Lwin and Phau, 2013). Hence, the identification of the proper 
audience for the advertisement is important to consider for advertisers when developing their advertisements.

Although theoretical and practical developments in the marketing field have advanced exponentially, it is still not known with certainty how to best frame a combination of ACE variables for a particular audience. Moreover, it is also important to probe how the consumer's attention mediates between ACE constructs and consumer behavior. Hence, in a highly sophisticated advertising industry, these concepts still require further research. Although much of the research examines the behavior and profitable relationship with consumers, the industry and academic literature is silent about the prioritized combination of ACE mixes and attention levels in advertisement and their ultimate effect on consumers' behavior. Hence, it demands proper planning, research, and strategies from marketing professionals combined with consumer behavior analysis (Mendelson and Bolls, 2002; Brodie et al., 2011).

The purpose of this study is twofold. First, it aims to develop an appropriate ACE combination in the psychological realms of consumer behavior. It will not only elucidate the super-dominant combination of ACE mixes, but will also uncover subordinate levels which consist of specific emotions, celebrity endorsements and appeal drivers. Second, the study seeks to reveal the applicability of ACE mixes in measuring women's behavior through partial least squares path modeling (PLS-SEM), a novel approach to advertisement development and consumers' consumption behavior analysis. The study also highlights the mediating role of attention in this overall context which may influence the relationship between ACE constructs and women's consumption behavior. For this purpose, master level Chinese female students at the Fujian Medical University, Fuzhou China, were randomly engaged to participate in the present study with a total sample of 240 respondents. Since it is claimed that women are the most powerful consumers (Tomlinson, 2007), we take this as a basis to measure Chinese women's response towards ACE-based advertisements. Since some studies suggest that women express emotions three times, on average, more than the men do (Vigil, 2009), the results presented in this study may provide some guidelines to Chinese marketing and advertising professionals to effectively boost business volumes in China by influencing Chinese women's consumption and contagion behavior. ACE research dimensions encapsulated in this study may provoke constructive discussions on advertising and marketing in the Chinese context. This paper proposes a theoretical model which attempts to advance theoretical and practical knowledge with its findings.

\section{Literature review}

An advertisement is a non-personal communication processed through the media, which is paid and sponsored to promote the ideas, goods or services being offered in the advertisement and provides a platform to create awareness of the advertised products (Wijaya, 2012; Ayanwale et al., 2005; Kumar and Raju, 2013). Meanwhile, EAs generate an emotional response in the minds of consumers. It also influences the audience in making a purchase decision, raising awareness of the brand, and influencing their positive response in favor of the advertised product (Matthes et al., 2014; Niazi et al., 2012). Companies spend billions of dollars in developing marketing strategies and advertisements to influence the behavior of consumers. However, Lewis et al. (2012) note that such kinds of investment efforts are lost when consumers' desired 
responses are not obtained. This may be because consumers have different behaviors which are shaped by their emotions (Khuong and Tram, 2015).

Emotions are depicted as a universal language (Khuong and Tram, 2015) and a state of the mind, which are shaped by cognition, thinking and experiences with diversified feelings in order to bring a change to social and physical behaviors (Ekman, 1992; Foo, 2011; Oatley and Johnson-Laird, 2014). Emotions are often linked to actions, for example, gestures, posture, and facial movements, which enable respondents to manage their behaviors (Hakkak et al., 2016; Lewis et al., 2012). Consequently, behaviors could be positive (for example love, pride, happiness, joy, and warmth) or negative (for example guilt, greed, sadness, fear, and anger) (Roozen and Claeyes, 2009; Saad, 2011; Hakkak et al., 2016).

Academic literature sheds light on a variety of combinations of emotions, for example, basic (primary) emotions, complex (secondary) emotions, or a mixture of basic and complex emotions. Plutchik (1997) and Zammuner (1998) encapsulate basic emotions with sub-constructs of both positive and negative emotions,that is, fear, anger, joy, sadness, disgust, love, anxiety, surprise, compassion, etc. Bindu et al. (2007) further fuel the discussion with a classification of some other basic emotions, that is, pride, lust, ecstasy, rage, revenge, sorrow, shame, grief, enthusiasm, and hate in tandem with the basic emotions categorized by Plutchik and Zammuner. Bindu et al. further claim that these basic emotions may give birth to complex emotions as well which could include remorse, nostalgia, forgiveness, offense, disappointment, jealousy, cheer, hope, etc. However, Ekman's (2007) arguments are worth mentioning here, whereby he notes the universality of the basic emotions, that is, happiness, sadness, pride, fear, disgust, anger, and surprise. He suggests that these basic emotions are universally expressed and accepted by everyone regardless of time, place, and culture due to their common biological origin.

However, it has also been widely discussed that people who belong to different cultures may experience different emotions, and their behavior may also be dominated by contextual emotional developments (Boiger and Mesquita, 2012; Kidwell and Hasford, 2014). Behavioral intentions incorporate buying behavior in its diversified dimensional frames (Shiau and Luo, 2012; Alexandris et al., 2002). The diversity in consumers' behavior leads to different emotional responses to marketing stimuli which companies develop for consumers. Some researchers support the marketing notion that marketers should attempt to understand consumers' behavior towards promotional stimuli (Martin and Morich, 2011; Chu, 2011) as understanding consumers may shape better marketing strategies for them.

Since consumers may have a variety of consumption behaviors, shaped by their emotions (Khuong and Tram, 2015), there is a difference in advertising to men and women because both react differently to emotional stimuli (Iordan et al., 2013; Stern, 1999; Fischer et al., 2004; Oliver et al., 2000; Brody, 1997; Orth et al., 2012; Donges et al., 2012). It is noted that women may generate positive responses towards emotionally advertised stimuli (Fisher and Dube, 2005) and a stronger buying impulse, based on emotional feelings, may come from women themselves (Coley and Burgess, 2003). Women prefer long-term considerations in their decision-making and repeat buying is more important to females than to males (Bakshi, 2012). Moreover, Knerl (2010) notes that women may reinvest $90 \%$ of their income in their communities; however, their male 
counterparts only reinvest 30 to $40 \%$. This is evidence that suggests that women may form long-term relationships with companies that value them.

Many scholars have discussed women's emotional nature and their ultimate impact on consumption behavior (Cotte and Ritchie, 2005; Coley and Burgess, 2003). Vigil (2009) notes that women may have a strong response in understanding the emotions of others, and may express their emotions more than men do. Further, women's emotionally expressive behavior may influence the consumption behavior of other people around them, for example, friends, family members, and children (Khan and Nasr, 2011). This provides a valid basis for advertisers to consider women's emotions towards advertised stimuli and the resultant consumption behavior in order to effectively boost their business volume. Since consumers' consumption behavior may be influenced by their emotions (Khuong and Tram, 2015), advertisers inject emotional feelings into advertisements with the intention of capturing the attention of women and influence their consumption patterns (Coley and Burgess, 2003; Lwin and Phau, 2013). By doing so, professionals in the marketing and advertising fields have started to mix positive and negative emotional feelings while developing promotional stimuli. For example, skin care advertisements have been found to be effective in manipulating women's emotions and skin care product consumption pattern (La Tour et al., 1996; Cotte and Ritchie, 2005). Advertisers of skin care products first touch on the beauty enhancement feelings of women, and generate fear about bad skin tones if the advertised product is not used (Williams, 2011), and with the actor/actress showing depressed and sad face. Later, the fearful emotional feelings that have been invoked are dissipated with hope in the form of the consumption of the advertised product as a solution to enhance beauty, happiness, and pride which will allow the consumers to avail themselves of all of life's privileges (Kashyap, 2013; Shevde, 2008; Tehseem and Kalsoom, 2015; Witte, 1994). Hence, EAs continuously endeavor to influence the emotions of women and persuade them to buy the advertised product. This may also generate a plethora of better memories which the targeted audience may recall later (Muehling et al., 2014).

Thus, it is proposed that:

H1: Emotional feelings injected into an advertisement lead to significantly positive changes in the consumption behavior of women.

Sometimes desires, which are a confluence of emotions and state of mind, become more important than needs in a mature marketing environment. Consumers may desire intangible factors, for example, trust, love, fulfillment of dreams, and association with certain personalities, while evaluating and consuming the products being offered or advertised (Thwaites et al., 2012). Advertisers may attempt to market products which consumers may not need. They endeavor to influence consumers' consumption patterns favorably by capitalizing on the human emotions that might be triggered by their dreams and idols. Consumers sometimes perceive celebrities as their idols and become ready to emotionally align their buying and consumption styles with ways celebrities present (Thwaites et al., 2012). From this perspective, women's behavior may be more responsive to the products being endorsed by celebrities. Klaus and Bailey (2000) document that women consumers respond more positively to celebrity endorsement compared to men. Many studies have documented women's favorable behavior towards products endorsed by 
celebrities (Bush et al., 2004; Daneshvary and Schwer, 2000). Hence, celebrities' glamour is perceived to be transferred to women while consuming the endorsed product.

It has been documented that consumers between 16 and 34 years of age are more responsive to the purchase of products endorsed by celebrities (Pringle and Binet, 2005). A celebrity endorser, as defined by McCraken (1989, p. 310) and noted by Seno and Lukas (2007) is a person who has a public identity and uses his/her recognition to promote a consumer good by drawing consumers' attention in an advertisement. Hence, the importance of featuring celebrities and their seminal role in drawing attention to boost the buying or consumption of the advertised products has been widely acknowledged by advertisers (O’Mahony and Meenaghan, 1998). Agrawal and Kamakura (1995) solidify these notions and document increases in a company's stock prices when contracts with celebrities for the company's promotion are announced. Erdogen et al. (2001) document that about $25 \%$ of the advertisements in the United States (US) feature celebrities, and has become a fashionable phenomenon in the US retail business (Choi and Rifon, 2007).

However, marketers prefer to feature celebrities in their advertisements who are credible, attractive, and possess certain associations with their brand image (Hakimi et al., 2011). Billions of dollars are invested every year in various showbiz and sports' celebrity endorsement contracts. Famous sports and showbiz celebrities, for example, Cristiano Ronaldo, Megan Fox, and Tiger Woods, have been featured in advertisements in order to influence consumers' buying and consumption behavior Martin and Bush (2000). These celebrities have played instrumental roles in the advertisement industry. The female athlete Venus Williams, a tennis player who won the Wimbledon championship in 2002, signed contracts for the promotion of sportswear with Reebok International Inc. Chan (2010) documents that Hong Kong's media actively engage famous singers, movie actors, and athletes as spokespersons for their products and services in television commercials. The author also emphasizes that about half of Hong Kong's political campaigns also engage the services of celebrity endorsers for publicity. It is generally held that featuring celebrities in advertisements generate publicity, positive word-of-mouth, and are influential in capturing the attention levels of consumers (Buksa and Mitsis, 2011; Guillaume et al., 2010; Zhou and Whitla, 2013; Solomon and Bendickson, 2016).

Although featuring celebrities in advertisements have been considered effective in generating favorable responses among women (Klaus and Bailey, 2008), the success of the advertisement is still not guaranteed (Thwaites et al., 2012). This is because there are certain risks which are associated with featuring celebrities in advertisements. For example, Miciak and Shanklin (1994) document a successful celebrity endorsement in only one advertisement out of five which lived up to consumers' and advertisers' expectations. The desired functioning of the celebrities thus depends on properly featuring them according to the context in the advertisements. However, a famous face may still hold consumer's attention. Consumers may still enjoy a little extra entertainment, aspiration, and imagery while associating themselves with the celebrity's endorsed products (Pringle, 2004). Considering the featuring of celebrities in advertisements and theories about women's emotions and responses towards advertisements, it is proposed that: 
$\mathrm{H} 2$ : Featuring a celebrity in an advertisement leads to significantly positive changes in the consumption behavior of women.

Hollis (2010) notes that anything which looks interesting and enjoyable may capture consumers' attention. A story, a brand, or an advertisement itself could also capture attention levels. Marketers often endeavor to tell emotional stories about the products or services offered for sale (Hakkak et al., 2016). Hollis (2010) further maintains that humans are emotional and emotions have enough power to grab their attention. Consequently, strongly charged emotional events that develop strong memories among consumers shape their consumption behavior in a particular way. In this context, the appeal drivers in advertisements may determine the overall rhythm of emotions in advertisements. Emotional appeals may touch customers' heartstrings in order to engage them in purchasing the product (Swani et al., 2014; Wang et al., 2013). Emotional appeals may awake either negative or positive emotions, which in turn motivate the consumers' buying decisions. Marketers engage a lot of appeal drivers to influence human emotions. For example, consumers might consciously think that a steak may be delicious when he/she watches it on television. Further, if the sound of steak sizzling is added to the same advertisement, consumers may begin to crave the steak (Lewis et al., 2012).

Nowadays, companies are competing with each other with similar products or services; and it has become strategically necessary to offer products while highlighting them through diversified factors (Jordan, 2001). For example, consumers might prefer to watch adverts with soothing music that evoke feelings of positive reactions to the nice fragrance and color of coffee, ice-cream, etc. (Lii and Sy, 2009). Hence, the multidimensional involvement of execution factors, for example, music, colors, meanings, symbols, etc., may stimulate favorable or unfavorable behavioral responses of the audience. The desired generation of emotional stimuli may penetrate consumers' perception through the multidimensional engagement of colors, music, symbols, and meanings in the advertisements. Music is a sensational stimulus to set the overall flow of the advertisement. The penetration of music and sounds in adverts is increasing in modern marketing (Tomey, 2014). It has been documented that about $50 \%$ of an advertisement normally focuses on the music appeal driver in order to make the advertisement watchable (Mayer et al., 2008). Advertisers are continuously engaging various appeal drivers, for example, images, messages, improved picture quality, or background music, in order to arouse favorable emotional responses from consumers (Mogaji, 2015). Hence, these emotional advertising stimuli may capture the attention mechanism of consumers while shaping their behavioral responses (Percy and Rosenbaum-Elliott, 2012; Poels and Dewitte, 2006). Percy (2003) further supports the inclusion of emotional appeal drivers into advertisements. Many academic works on advertising have documented the emotional power of appeal drivers in order to shape consumption behavior. Studies have shown that an impactful advertisement can be developed with a premier focus on an advertising color (Lichtlé, 2007), image or picture quality (Small and Verrochi, 2009), music (Tomey, 2014; Lii and Sy, 2009; Mayer et al., 2008), and message being delivered (Mogaji, 2015). Additionally, Cacioppo and Petty (1989) note that the advertising message should be made relevant to the overall context of the advertisement in order to create the desired results. The presentation of appeal drivers in the advertisement may draw consumers' attention towards advertisement, which may ultimately impact their consumption patterns (Zeitlin and Westwood, 1986). The impact of 
advertising music, message, picture quality, and color appeal drivers on women's responses has been researched by academic scholars in various fields (Park and Young, 1986; Martin-Santana et al., 2015; Stoeckel et al., 2007; Lichtlé, 2007). The majority of such research shows the positive response of women towards those adverts which incorporate emotional appeal drivers while developing the advertisements.

Hence, an impactful advertisement may incorporate a variety of appeal drivers, for example, tone, lighting, message, sound, characters, picture quality, music, and different color combinations. Furthermore, these provide a base for the other elements of the advertisement and increase their effectiveness multifold. Since consumers respond more to catchy advertisements, these tactics determine the attention levels towards the advertisement, which ultimately turn into favorable consumption behavior triggered by the advertisements (Saad, 2011; Marie, 2009).

Thus, it is proposed that:

H3: Appeal drivers in advertisements lead to significantly positive changes in the consumption behavior of women.

The literature discussed in this study has illuminated the concepts of emotional advertising stimuli, with a focus on appeal drivers (A), celebrity endorsement (C), and emotions (E), and their likely associative influence on women's consumption behavior. Hence, emotional marketing has acknowledged the importance of women's feelings, emotions, motivations, and interest levels in the buying decision-making process. Advertisers strategically endeavor to grab the attention of women to elicit a favorable consumption response (Rai, 2013; Rytel, 2010; Saad, 2011). The ACE based exposure of emotional stimuli may impact women's buying or consumption behavior after passing through their attention filters. This notion can further be solidified with the premises of the advertising response model (ARM) discussed by Mehta (1994). Mehta's ARM presumes that consumers' attention places itself in between the exposure to advertising stimuli for a peripheral route, which is focused on advertising execution factors, and its ultimate impact on their buying behavior. ARM's notions of exposure to advertising stimuli can be linked and discussed in light of associative learning theory (ALT) as well, which supports the association of various created concepts, as mentioned by Till and Busler (2000). The authors further note that conceptual linkages between various concepts, for example, an endorser's communicated emotions, messages, or fit with other advertising executional appeal drivers, may configure exposure to networks of stimuli which may prompt the desired response among women. The advertising execution factors encapsulated in the present study are color, picture quality, music, and message in tandem with emotions which will be shown by various celebrity endorsers.

The premises of ARM support the notion of the mediating role of attention for emotional advertising exposure, which is also supported by ALT, and women's consumption behavior discussed in detail. Emotional advertising and its seminal role in influencing consumers' behavior through their attention filters has also been discussed by many academic scholars (Heath, 2007; Heath et al., 2006). More precisely, the featuring of celebrities and their exhibited emotions in tandem with the advertising execution factors have been discussed by researchers in order to explain their impact on women's attention and consumption behavior (Solomon, 2002; Agrawal and Kamakura, 1995; Stoeckel et al., 2007; Park and Young, 1986; Klaus and Bailey, 2008; Lwin and Phau, 2013). The discussed theories provide grounds to postulate that: 
H4a: The relationship between emotional feelings created in advertisements and women's consumption behavior is positively mediated by attention.

H4b: The relationship between a celebrity being featured in advertisements and women's consumption behavior is positively mediated by attention.

H4c: The relationship between appeal drivers in advertisements and women's consumption behavior is positively mediated by attention.

\section{Measurement model}

The AIDA model was developed as a behavioral model to generate awareness and interest in an audience through advertisements for products or services. Moreover, the model proposes that attention leads to ultimate actions, which may be described as consumption decision-making and buying (Gharibi et al., 2012; Wijaya, 2012; Hackley, 2005). The AIDA model suggests that advertisements may hold attention by creating interest in the advertised product and shapes the desires of the audience to take action, i.e., creates a behavioral response to the advertised stimuli (Wijaya, 2012). EA emphasizes emotions, eye-catching, peripheral and symbolic cues, through for example, colorful ads, the use of celebrities, etc.; however, it differs from traditional advertisement, which focuses solely on product attributes, in terms of grabbing an audience's attention. In the emotional advertising context, the AIDA model brings together traditional and emotional advertising which is regarded as highly persuasive ground for the advertisers to work with which can effectively hold an audience's thoughts and influence their consumption patterns (Zulkifly and Firdaus, 2014). It may also be considered as a concrete advertising base on which to build theory.

On the basis of the aforementioned literature, addressing the use of appeal drivers (A), celebrity endorsement (C), and emotions (E) in advertisements and their likely association through ALT and ARM, a theoretical model is presented in Fig. 1 which encapsulates exposure to the ACE-based advertisement in order to influence women's consumption behavior with a mediating role for attention. The present study's ACE model, which is theoretically embedded within the ARM and

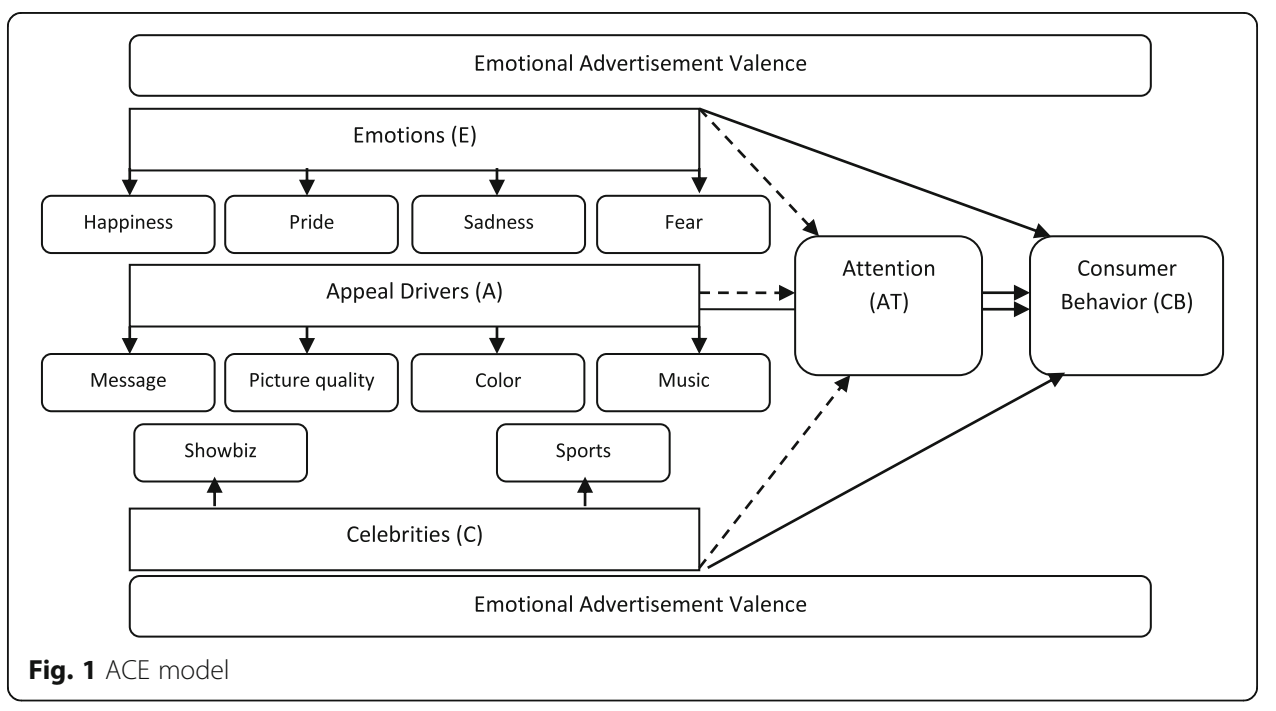


AIDA premises where exposure to advertisement is presented and its ultimate impact on the audience's behavior is documented integrates the subordinate levels of human emotions (i.e., happiness, pride, sadness, and fear), appeal drivers (i.e., message, picture quality, music, and colors), and celebrity endorsement (i.e., showbiz and sports) constructs in order to show their influence on women's responses (modeled with attention, interest, and consumption behavior). The emotions of happiness, pride, sadness, and fear are distilled from the literature by Cotte and Ritchie (2005), Williams (2011), and Rytel (2010) and are also a part of basic emotions as identified by Ekman (2007), Plutchik (1997), and Zammuner (1998). These emotions are encapsulated into the ACE model considering their nature of universality (Ekman, 2007). The showbiz and sports celebrities are considered in keeping with the arguments of Martin and Bush (2000). More precisely, the discussion by Chan (2010) in the Chinese context was considered while depicting celebrities' role in the ACE framework in the present study.

Kotler and Armstrong (2016) document that consumers' social, symbolic, or psychological needs may best be targeted with emotional appeal drivers in order to stir up their motivation for the product/service consumption. Hence, the right choice of advertising appeal drivers is important while developing advertising which may ultimately impact the success or failure of advertisement (Turley and Kelley, 1997). Considering these viewpoints, appeal drivers were chosen from the literature in this study focused on message, picture quality, music, and color as these were identified as important by many scholars (Mogaji, 2015; Tomey, 2014; Lichtlé, 2007; Young and Park, 1986; Small and Verrochi, 2009; Lii and Sy, 2009). Hence, the constructs presented in the ACE model were developed out of the review of theories, models, and existing literature on emotions, advertisements, consumer behavior and market mechanisms coupled with gender differentials.

\section{Methodology}

\section{Research design}

For effective marketing stimuli, it is important to understand consumers' choice appropriately in order to influence their buying and consumption behavior (Kotler and Armstrong, 2016). Despite the recent stock market and currency depreciating problems, Chinese consumers remain motivated and are resilient in their modern consumption behavior. Atsmon et al. (2012) note that the Chinese economy tripled between 2000 and 2010. This growth rate has attracted business investors from across the globe to enter Chinese business markets (Zipser et al., 2016). However, Chinese consumer behavior is evolving rapidly with expected higher income levels between 2010 and 2020, which may challenge conventional marketing and advertising strategies as well (Zipser et al., 2016; Atsmon et al., 2012). These are all reasons to understand Chinese consumer behavior appropriately, in the current context. Since Chinese women's participation in higher paid jobs is increasing, they are becoming more concerned about lifestyle, beauty, and wellness (Atsmon et al., 2012). Moreover, some research indicates that concerns about physical beauty among Chinese are making luxury beauty products very popular ( $\mathrm{Li}$ and $\mathrm{Su}, 2007)$. The products which address wellness, lifestyle, and beauty needs have been deeply involved in exploiting human emotions. These 
narrations solidify the reason to conduct research on women's consumption behavior in the Chinese context. When a product is launched in China, advertising on Chinese television is a traditional way to reach Chinese consumers (Giele, 2009). It has been claimed that the emotional considerations will dominate Chinese consumers' buying decisions by 2020 (Atsmon et al., 2012). These arguments strengthen the research justifications presented in this study to conduct research on emotional advertising strategies in electronic media and within the Chinese context.

For these reasons and to test the proposed hypotheses, voluntary respondents were invited from the student population at the Fujian Medical University, Fuzhou, China. The chosen population was female and, to match the consent agreement requirement, at least 19 years of age (Lewis et al., 2012). The participants were enrolled in university at the time of this research work. A total of 240 respondents, randomly chosen, voluntarily participated in the survey. The research design was a laboratory-based survey, which was administered to measure ACE variables' association and its ultimate impact on consumption patterns. The research design also supports the measurement of the mediation effect of attention levels between ACE variables and consumption behavior.

\section{Participants and research stimuli development}

The proposed hypotheses were tested by providing a believable scenario to the study participants. Respondents were invited to imagine that the situation being presented was a real situation. The situations depicted through the scenarios may increase the validity and direction of consumers' responses in different contexts (Smith et al., 1999). A scenario was designed in advance. The scenario allowed the respondents to choose the best combination of ACE variables, and develop their own advertisement, which would capture their attention and possibly convince them to buy the product (consumption behavior) if a product is advertised with the developed ACE mix. The guidelines to develop the scenario were adapted from the Central Park New York context, which was also used by Lee (2012). However, it was adjusted according to the nature of this study through discussion with six persons, including one professor, two marketing instructors, one student, and two advertising professionals (Appendix 1).

The procedure allowed the participants to listen to the scenario, explained by a neutral experiment facilitator who was engaged to minimize the biases of the study, and then to choose the ACE variables. The variables included message, colors in the ads, music, picture quality, the featuring of a showbiz celebrity or a sports celebrity, and the emotional feelings of happiness, sadness, fear, and pride (which were being shown through the faces of the celebrities), were provided as a toolkit to develop the EAs.

The celebrities' pictures, showing emotional expressions, were adapted from IMBD popular Hollywood actors and actresses (Engerror, 2013), and Gaines's (2016) list of popular athletes in the world. The stimuli included multiple expressions to show happiness, sadness, fear, and pride which were considered appropriate for the psychological experiment. The sound appeal drivers were adapted from common sound clips heard in online advertisements (Appendix 2) which were adapted from Lewis et al. (2012), adjusted according to the nature of the study. The participants were offered headphones to listen to the sound stimulus via lab assisted computers. Photoscape 3.7 was provided as a tool to adjust the picture 
quality and color tone, and open access to the internet was arranged to write or select a message of any kind which the participants wanted to incorporate while developing the advertisements. McLeod's (2008) guidelines were followed to conduct the psychological experiment in this empirical study. The researchers controlled the laboratory environment to ensure that lighting and noise were at comfortable levels.

The questionnaire was used to measure the response of the participants to the $\mathrm{ACE}$ variables and their attention levels. The respondents' interest and attention levels were measured to determine their association with and priority of the ACE dimensions. To measure the interest and attention levels of the study respondents towards the ACE variables, the participants were asked to rate their response on a 7-point Likert scale (ranging from strongly disagree to strongly agree). The developed instrument for the study was adapted from the studies of Doherty et al. (1995), Richins (1997), Bijmolt et al. (1998), Lewis et al. (2012), Wei and Lu (2013), and Dittmar et al. (2004) in order to measure the attention levels and consumption behavior of the audience. The adapted instruments were adjusted according to the context of the study, and for the appropriate understanding of the participants. Advertisers use some general demographic approaches to influence audiences as well. A lot of factors may influence women to behave a certain way in a certain situation, for example, age, education, and income. A consumer's age, personality, occupation, education, economic circumstances, values, and lifestyle are all personal characteristics which are likely to influence consumer behavior (Kaputa, 2009; Holmberg and Ohenfeldt, 2010; Bakshi, 2012; Knerl, 2010). In order to appeal to the audience for a desired response, marketers may use consumers' demographics information while developing advertisements (Lynn, 2011; Ashe-Edmunds, 2012).

Therefore, demographic questions on age, education, and work status were included in the questionnaire for analysis purpose in the study context. The number of study respondents is considered appropriate because in the rating scale, a sample size with over 100 participants is appropriate to estimate the results with a margin error of $+/-10 \%$ (Souro, 2010). The demographic profiles of the study participants are listed in Table 1. Immediately following the development of the ACE advertisement, the participants were requested to fill in the questionnaires. Based on an initial pilot study of 30 respondents, the Cronbach's $\alpha=0.76$ shows high internal consistency, and hence was considered appropriate for further study (Hair et al., 1998).

\section{Statistical analysis}

PLS-SEM, more precisely, the SmartPLS 3.2.6 (Ringle et al., 2015) was used to analyze the study model. The suitability of PLS-SEM was determined due to certain reasons, for example, (1) this research work's scope is extended to predict and explain the variance levels in certain target constructs, (2) the study's research paradigm is complex, and, (3) the interaction of emotions, appeal drivers, and celebrity endorsement in the advertisement with attention level and consumption behavior is a new element that can add to theory development and thus provides an opportunity to shed light on new processes. 
Table 1 Demographic profiles of the respondents

\begin{tabular}{|c|c|c|c|c|}
\hline Variable & Category & Frequency & Percent & Cumulative Percent \\
\hline \multirow[t]{3}{*}{ Gender } & Male & 0 & 0 & 0 \\
\hline & Female & 240 & 100 & 100 \\
\hline & Total & 240 & 100 & \\
\hline \multirow[t]{3}{*}{ Nationality } & Others & 0 & 0 & 0 \\
\hline & Chinese & 240 & 100 & 100 \\
\hline & Total & 240 & 100 & \\
\hline \multirow[t]{4}{*}{ Age } & $20-25$ & 136 & 56.67 & 56.67 \\
\hline & $26-30$ & 83 & 34.58 & 91.25 \\
\hline & $31-35$ & 21 & 8.75 & 100 \\
\hline & Total & 240 & 100 & \\
\hline \multirow[t]{4}{*}{ Qualification } & Undergraduate & 71 & 29.58 & 29.58 \\
\hline & Graduate & 129 & 53.75 & 83.33 \\
\hline & Post-graduate & 40 & 16.67 & 100 \\
\hline & Total & 240 & 100 & \\
\hline \multirow[t]{6}{*}{ Work Status } & Full time student & 138 & 57.5 & 57.5 \\
\hline & Working part time & 58 & 24.17 & 81.67 \\
\hline & while attending school & & & \\
\hline & Working full time & 44 & 18.33 & 100 \\
\hline & while attending school & & & \\
\hline & Total & 240 & 100 & \\
\hline
\end{tabular}

\section{Results}

\section{Evaluation of measurement model}

Table 2 results indicate that all loading items of the measurement model are greater than 0.70 and are found significant at a $0.05 \%$ level. It shows the items' level convergent validity as well. Composite reliability Cronbach's alpha values are more than 0.70 , indicating acceptable reliability levels. Moreover, the AVE values of all items at the construct level are found to be more than 0.50. The heterotrait-monotrait (HTMT) values in all items are below 0.90 (Henseler et al., 2015), as mentioned in Table 3, which demonstrates the study's discriminant validity.

\section{Structural model evaluation}

This study shows path coefficients and coefficients of determination $\left(R^{2}\right)$ for structural model measurement (Hair et al., 2013). Moreover, a bootstrapping method (resampling) adopted with 5000 for the observations as the original sample $(n=240)$ for $t$-values and standard error (Hair et al., 2013). Magnitude and signs of path coefficients (as mentioned in Table 4 and Fig. 2) estimate the path relationship among the model variables.

Coefficients of determination $\left(R^{2}\right)$ values for endogenous variables are found adequate in this study (i.e., above the $10 \%$ level) (Falk and Miller, 1992). $R^{2}$ values for attention (0.605) and consumer behavior (0.709) are moderate and considered appropriate for the study (Fig. 2). Beta and $p$ values in Table 4 results show that the direct relationship of emotions ( $\beta=0.223$ (5.836), $p=0.001$ ), appeal drivers $(\beta=0.231(4.462), p=0.000$ ) 
Table 2 Model Measurement

\begin{tabular}{|c|c|c|c|c|c|c|}
\hline Constructs & Items & LVs & $C R$ & $a$ & AVE & $\mathrm{R}^{2}$ \\
\hline Emotions (E) & & & & & & - \\
\hline \multirow[t]{2}{*}{ Hope } & E1 & 0.807 & 0.851 & 0.783 & 0.663 & \\
\hline & E2 & 0.811 & & & & \\
\hline \multirow[t]{2}{*}{ Pride } & E3 & 0.752 & 0.786 & 0.817 & 0.681 & \\
\hline & E4 & 0.773 & & & & \\
\hline \multirow[t]{2}{*}{ Sadness } & E5 & 0.837 & 0.793 & 0.849 & 0.652 & \\
\hline & E6 & 0.808 & & & & \\
\hline \multirow[t]{2}{*}{ Fear } & E7 & 0.819 & 0.825 & 0.825 & 0.661 & \\
\hline & E8 & 0.794 & & & & \\
\hline Appeal Drivers (A) & & & & & & - \\
\hline \multirow[t]{2}{*}{ Message } & A1 & 0.835 & 0.788 & 0.721 & 0.585 & \\
\hline & $\mathrm{A} 2$ & 0.786 & & & & \\
\hline \multirow[t]{2}{*}{ Picture quality } & A3 & 0.822 & 0.857 & 0.746 & 0.637 & \\
\hline & A4 & 0.817 & & & & \\
\hline \multirow[t]{2}{*}{ Color } & A5 & 0.773 & 0.810 & 0.717 & 0.593 & \\
\hline & A6 & 0.741 & & & & \\
\hline \multirow[t]{2}{*}{ Music } & A7 & 0.832 & 0.863 & 0.733 & 0.539 & \\
\hline & A8 & 0.818 & & & & \\
\hline Celebrities (C) & & & & & & - \\
\hline \multirow[t]{2}{*}{ Showbiz } & $\mathrm{C} 1$ & 0.853 & 0.811 & 0.738 & 0.675 & \\
\hline & C2 & 0.827 & & & & \\
\hline \multirow[t]{2}{*}{ Sports } & C3 & 0.877 & 0.865 & 0.716 & 0.611 & \\
\hline & C4 & 0.846 & & & & \\
\hline \multicolumn{7}{|l|}{ Attention (AT } \\
\hline & AT1 & 0.776 & 0.901 & 0.855 & 0.701 & 0.605 \\
\hline & AT2 & 0.862 & & & & \\
\hline & AT3 & 0.863 & & & & \\
\hline \multirow[t]{3}{*}{ Consumer Behavior (CB) } & CB1 & 0.861 & 0.921 & 0.887 & 0.745 & 0.709 \\
\hline & CB2 & 0.873 & & & & \\
\hline & CB3 & 0.856 & & & & \\
\hline
\end{tabular}

Note: All loadings are significant at $0.05 \%$ level of significance (2-tailed)

$L V$ Loading Values, C.R Composite Reliability, a Cronbach's alpha, AVE Average Variance Extracted, $R^{2}$ Coefficient of Determination

Table 3 Heterotrait monotrait (HTMT) analysis results

\begin{tabular}{lllll}
\hline HTMT & 1 & 2 & 3 & 4 \\
\hline 1 Emotions & & & & \\
2 Appeal Drivers & 0.46 & & & \\
3 Celebrities & 0.42 & 0.61 & & \\
4 Consumer Behavior & 0.44 & 0.59 & 0.58 & 0.68 \\
5 Attention & 0.55 & 0.64 & 0.62 & \\
\hline
\end{tabular}


Table 4 Path coefficients of model and significant testing of hypotheses (Direct Effect)

\begin{tabular}{lllll}
\hline Structural Path & Path Coefficients (t-value) & Confidence Interval & $P$-value (0.05\%) & Results \\
\hline$E \rightarrow C B$ & $0.223(5.836)$ & $(0.152-0.305)$ & 0.001 & Accepted \\
$A \rightarrow C B$ & $0.231(4.462)$ & $(0.132-0.342)$ & 0.000 & Accepted \\
$C \rightarrow C B$ & $0.082(2.733)$ & $(0.023-0.143)$ & 0.004 & Accepted \\
AT $\rightarrow$ CB & $0.348(7.924)$ & $(0.262-0.432)$ & 0.000 & \\
E $\rightarrow$ AT & $0.331(7.826)$ & $(0.247-0.413)$ & 0.000 & \\
A $\rightarrow$ AT & $0.301(5.472)$ & $(0.192-0.408)$ & 0.011 & \\
$C \rightarrow$ AT & $0.094(2.523)$ & $(0.018-0.171)$ & 0.001 & \\
\hline
\end{tabular}

and celebrities $(\beta=0.082(2.733), p=0.004)$ with consumer behavior are highly significant at $0.05 \%$ level. These results provide valid support for the proposed hypotheses $\mathrm{H} 1, \mathrm{H} 2$ and $\mathrm{H} 3$.

\section{Mediation testing and analysis}

Non-parametric bootstrapping was applied to measure the mediating effect significance (Hair et al., 2013). Results in Table 5 show that the indirect/mediation between emotions, appeal drivers, celebrity endorsement, and consumer behavior is significant (i.e., $t>1.96$ at $p=0.05 \%$ ). However, the indirect/mediation beta value effects are less than the direct beta value effects for each related construct. It shows that the mediation variable (attention levels) absorbed some percentage of the direct effect as well (Hair et al., 2013). These results support the proposed hypotheses H4a, H4b and H4c. Since the indirect effect in this study is significant between the constructs with absorption effect, it justifies the mediation requirement effect mentioned by Hair et al. (2013). Hence, bootstrapping analysis results, shown in Table 4, meet the necessary requirements for a mediator measurement effect. VAF (Variance account for) results in Table 5 are found to be between $20 \%$

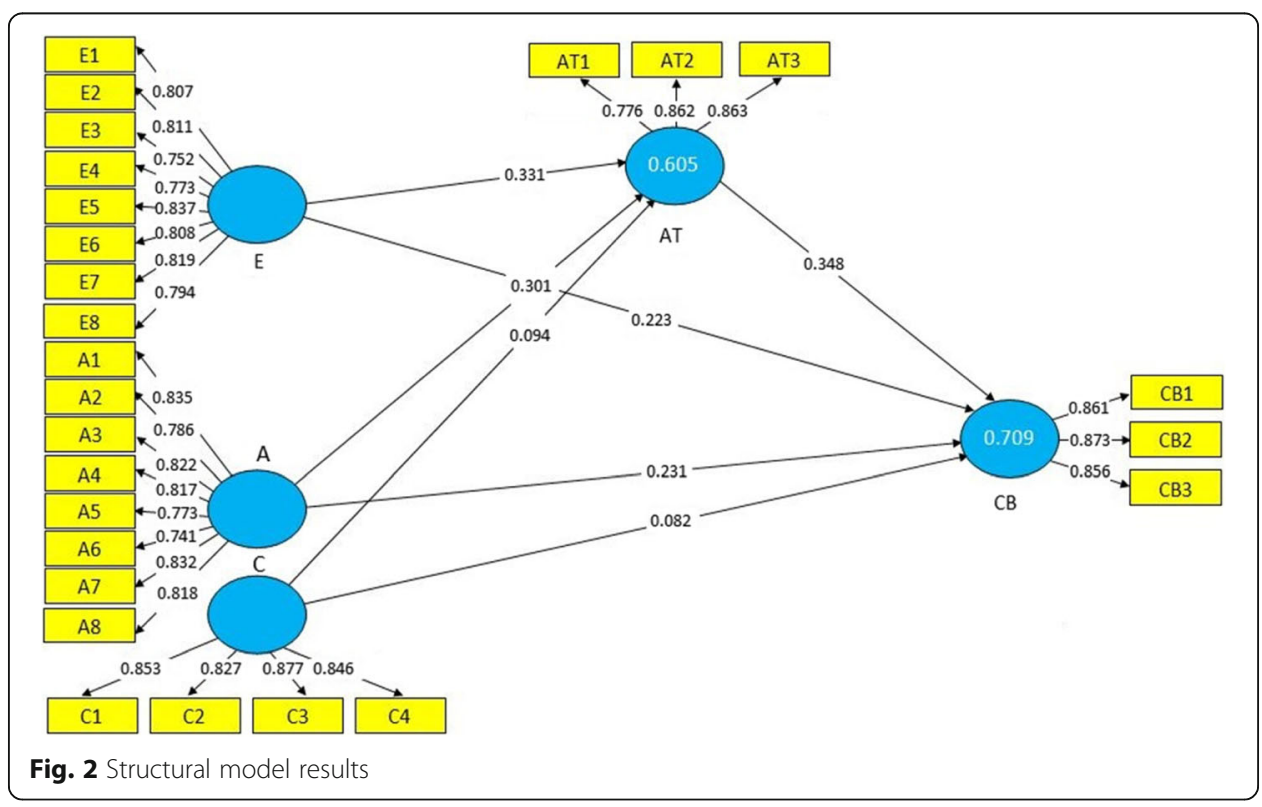


Table 5 Bootstrapping Mediation test (Indirect / Mediation Effect)

\begin{tabular}{|c|c|c|c|c|c|c|}
\hline $\begin{array}{l}\text { Structural } \\
\text { Path }\end{array}$ & $\begin{array}{l}\text { Direct Effect (t- } \\
\text { Value) }\end{array}$ & $\begin{array}{l}\text { Indirect Effect (t- } \\
\text { Value) }\end{array}$ & $\begin{array}{l}\text { Total } \\
\text { Effect' }\end{array}$ & $\begin{array}{l}\text { VAF } \\
(\%)\end{array}$ & Interpretation & Results \\
\hline \multirow[t]{2}{*}{$\mathrm{E} \rightarrow \mathrm{AT} \rightarrow \mathrm{CB}$} & 0.223 & 0.114 & 0.337 & 34.16 & $\begin{array}{l}\text { Partial } \\
\text { Mediation }\end{array}$ & $\overline{\text { Accepted }}$ \\
\hline & $(5.836)$ & $(5.686)$ & & & & \\
\hline \multirow[t]{2}{*}{$\mathrm{A} \rightarrow \mathrm{AT} \rightarrow \mathrm{CB}$} & 0.231 & 0.103 & 0.334 & 31.24 & $\begin{array}{l}\text { Partial } \\
\text { Mediation }\end{array}$ & Accepted \\
\hline & $(4.462)$ & $(4.236)$ & & & & \\
\hline \multirow[t]{2}{*}{$\mathrm{C} \rightarrow \mathrm{AT} \rightarrow \mathrm{CB}$} & 0.082 & 0.034 & 0.116 & 29.12 & $\begin{array}{l}\text { Partial } \\
\text { Mediation }\end{array}$ & Accepted \\
\hline & $(2.733)$ & $(2.476)$ & & & & \\
\hline
\end{tabular}

VAF variance accounted for, $n . s$ not significant; $|t|>=1.96$ at $p=0.05$ level; The VAF $>80 \%$ indicates full mediation, $20 \% \leq \mathrm{VAF} \geq 80 \%$ shows partial mediation while VAF $<20 \%$ is no mediation(Ali \& Park, 2016)

to $80 \%$ which identifies the mediation effect of attention levels on emotions, appeal drivers, and celebrities as partial mediation (Ali and Park, 2016).

The ranking analysis shows that overall the participants positively preferred music and color appeal drivers over the other appeal drivers being tested in the present study with the highest mean values (i.e., $M e a n_{\text {music }}=5.46$, $M e a n_{\text {colors }}=4.55$ ) and lowest standard deviation values comparatively (i.e., $S . D_{\text {music }}=1.53$, S.D $D_{\text {colors }}=1.79$ ) as compared to the other appeal drivers $\left(\right.$ Mean $_{\text {picture }}=4.38, S . D_{\text {picture }}=1.82 ;$ Mean $_{\text {message }}=3.34$, $S . D_{\text {message }}=1.88$ ). This is shown in Table 6 and Fig. 3. Likewise, the study respondents positively preferred the emotions of happiness and pride over the other emotions being tested with the highest mean values (i.e., Mean happiness $=5.86$, Mean $_{\text {pride }}=4.43$ ) and the lowest standard deviation values (i.e., $S . D_{\text {happiness }}=1.52$, S. $D_{\text {pride }}=1.80$ ) as compared to the other emotional stimuli $\left(M_{\text {ean }} n_{\text {fear }}=4.31, S . D_{\text {fear }}=1.87 ;\right.$ Mean $_{\text {sadness }}=3.28$, $\left.S . D_{\text {sadness }}=1.90\right)$. This is shown in Table 7 and Fig. 4 . In terms of celebrity choice, a celebrity endorser from the showbiz industry was preferred, with a mean value of 5.67 and low standard deviation value of 1.55 , over a sport celebrity $\left(\right.$ Mean $_{\text {sports }}=4.58$, $\left.S . D_{\text {sports }}=1.69\right)$. This trend has been summarized in Table 8 and Fig. 5.

\section{Discussion}

In this research, the antecedents to women's consumption behavior are depicted to study the proposed hypotheses while highlighting some new insights in the spheres of emotional responses to ACE-based advertising. It is evident that the specific appeal drivers, celebrity endorsements, and the kind of emotional feelings generated from the advertisement may impact the consumption patterns of women. It has been found that,

Table 6 Most preferred Appeal Drivers

\begin{tabular}{ll}
\hline Music & Colors \\
\hline 1 & 2 \\
Mean $=5.46$ & Mean $=4.55$ \\
S.D $=1.53$ & S.D $=1.79$ \\
Message & Picture quality \\
4 & 3 \\
Mean $=3.34$ & Mean $=4.38$ \\
S.D $=1.88$ & S.D $=1.82$ \\
\hline
\end{tabular}




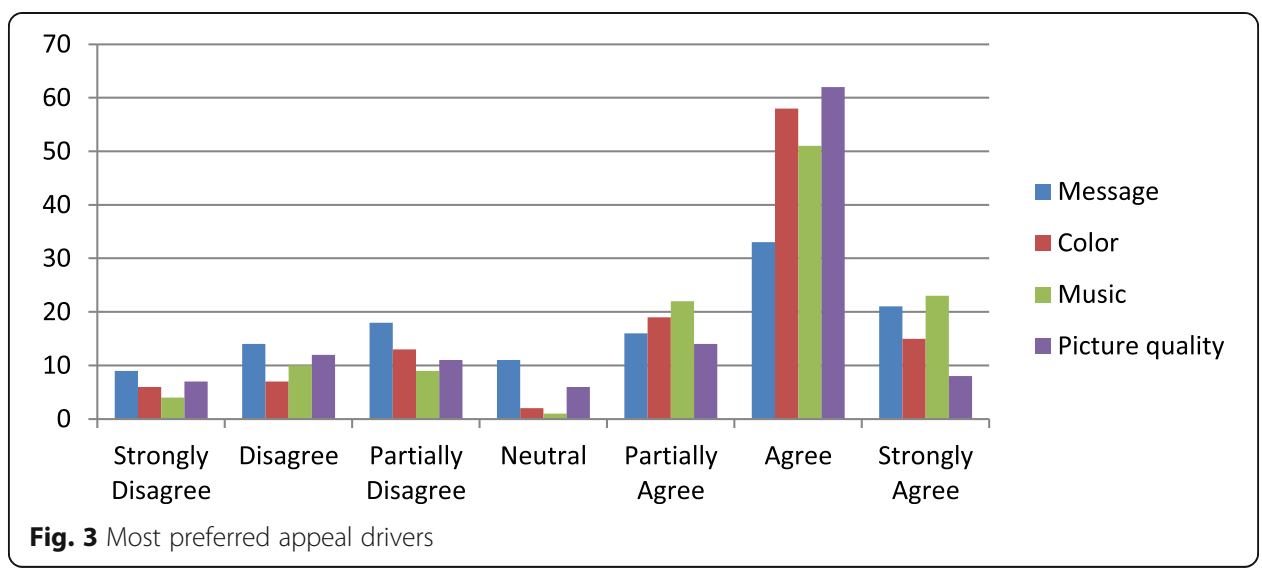

as expected, interesting and eye catchy advertisements may hold the attention levels of Chinese women which also mediates the direct effect of ACE constructs on their consumption behavior. Although all the ACE variables (appeal drivers, celebrity endorsements, and emotions) show their influence on Chinese women's consumption behaviors, however, the resulting robustness suggests that Chinese women are attracted to advertisements based on happy emotions with showbiz celebrities' endorsement, music, and the colors themes. The demographic profiles of Chinese women show some interesting insights. The age cohorts of Chinese women were found to have a significant and pervasive impact on their ACE choice and consumption behavior, followed by their work status. This could be a change in the preferences of Chinese women with the rise in their age cohorts, and good or bad work conditions which likely influence their behaviors and lifestyles.

\section{Contribution and implications}

This research work contributes to the growing knowledge of marketing and advertisement theory that investigates the relationship between emotions, appeal drivers, celebrity endorsement, attention levels and consumption behavior. This relationship is investigated by analyzing the mediating effect of attention level as an important process ACE employs to increase consumption patterns. Based on the complete nomological web weaved into the research model showed in Fig. 2, the PLS-SEM statistical analysis provides supporting results to the research objective of this study: to illuminate the best combination to be adopted while developing EAs, the best audience for ACE mix based EAs and to reveal how to capture the attention and influence the consumption

Table 7 Most preferred emotions

\begin{tabular}{ll}
\hline Happiness & Pride \\
\hline 1 & 2 \\
Mean $=5.86$ & Mean $=4.43$ \\
S.D $=1.52$ & S.D $=1.80$ \\
Sadness & Fear \\
4 & 3 \\
Mean $=3.28$ & Mean $=4.31$ \\
S.D $=1.90$ & S.D $=1.87$ \\
\hline
\end{tabular}




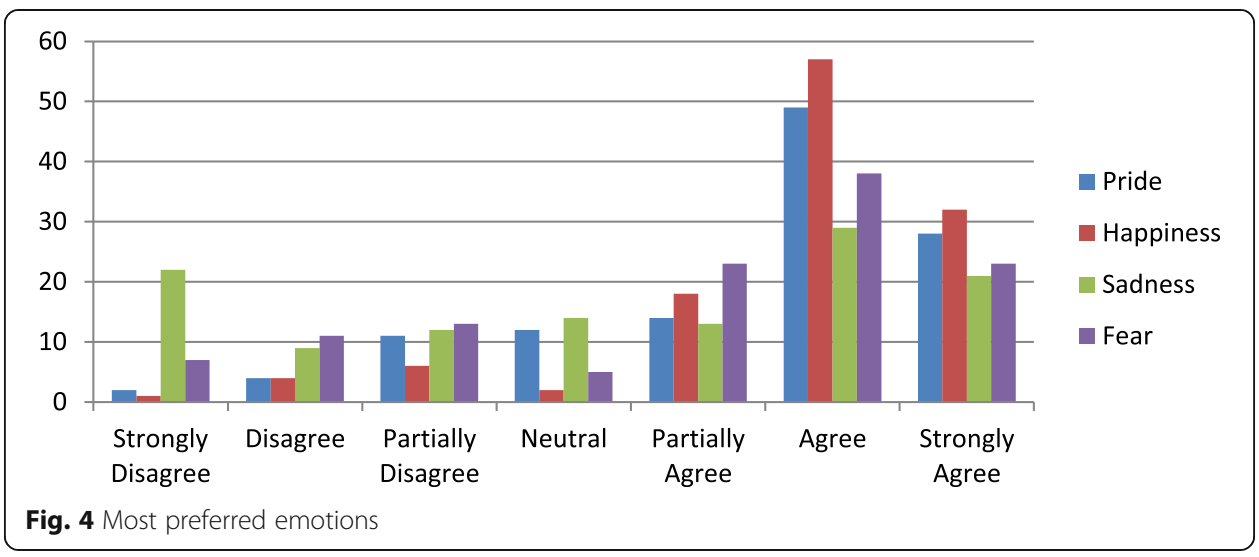

behavior of the audience through EAs. The study shows that women's response, particularly Chinese women's response, was primarily driven by their interest and attention levels induced by a specific ACE combination (comprised of showbiz celebrity endorsers showing happy emotions with music and colors) in the advertisement. The results advance the theory and conceptualization of the celebrity endorsement and their good fit in the EAs, which were previously unknown (Erdogan et al., 2001; Agrawal and Kamakura, 1995). Moreover, attention levels significantly mediate the relationship between emotions, appeal drivers, celebrity endorsements and Chinese women's consumption behavior. This research work provides empirical grounding for some of the theoretical assumptions surrounding EAs and its developments and measures the magnitude of consumer response. This research work is one of the few efforts that measures the depth and multidimensional nature of EA development, with ACE combinations, and women's consumption response in a Chinese context.

It is strategically important to determine the appropriate target audience for the advertising because consumers have different demographics. Considering age cohorts, background information, likes and dislikes, income, location, and challenges being met by the audience provide valid grounds to launch marketing and advertising campaigns. Campaigns can highlight how the advertised products and services provide the best solution to their problems. As certain groups of women differ from other women, products should be positioned uniquely for their target markets. Incorporating all advertising tactics to target all women would provide nothing for the consumer or business (Knerl, 2010). Although outside the frame of the present study, an important direction for future study would be to investigate the application of ACE combinations on male consumers. The study could further be extended to examine memory and brand loyalty among the male and female consumers. ACE combinations do not need to be restricted to gender influences on consumption, but could be deployed in every kind of business: from FMCG (Fast moving consumer goods), technology-intensive

Table 8 Most preferred type of celebrity

\begin{tabular}{ll}
\hline Showbiz & Sports \\
\hline 1 & 2 \\
Mean $=5.67$ & Mean $=4.58$ \\
S.D $=1.55$ & S.D $=1.69$ \\
\hline
\end{tabular}




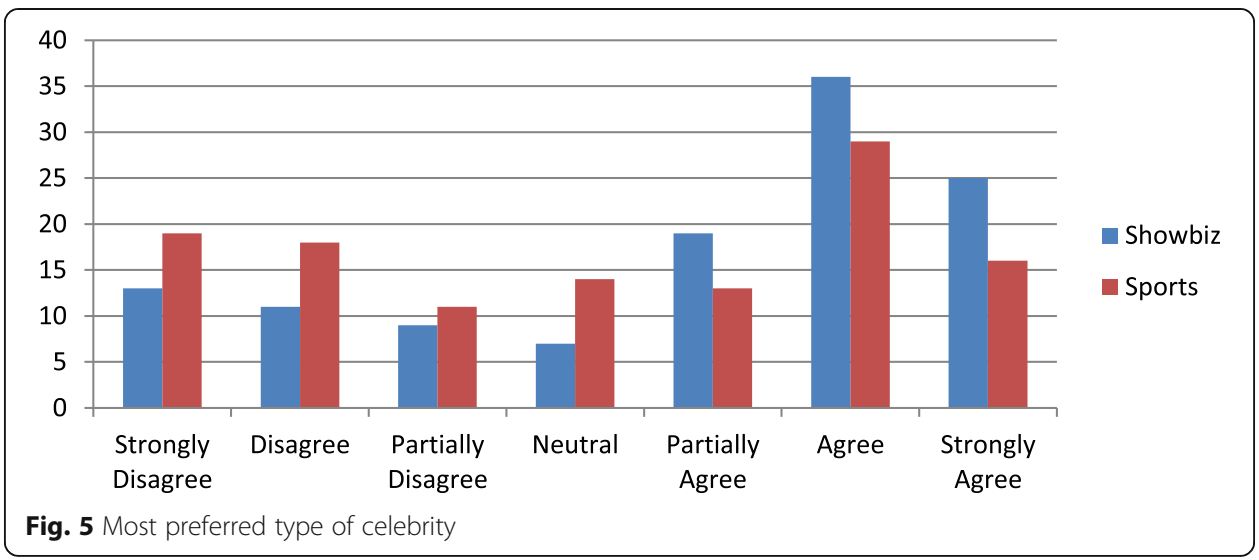

industries (e.g., computers, mobile phones, etc.), pharmaceutical industries, tourism and hospitality industries to destination marketing contexts, etc. However, the use of ACE combinations in advertisements requires proper policy making and investment from marketing professionals and advertisers, to achieve conventional goals (i.e., profits and market share maximization, etc.). It may hold the attention of the audience and confirm to the concepts of Guerilla Marketing, as mentioned by Levinson (2014), and brand loyalty. The purpose of this study is not only to highlight the areas which are not studied or understudied, but also to bridge theoretical and practical gaps through empirical research. It is an attempt to advance the theoretical and practical knowledge of the field. Further research in this area may better validate the association of ACE variables and explore new dimensions that may eventually be shown to influence consumer behavior. This study incorporated some sub-constructs of ACE variables. Future research may extend the focus with different combinations of ACE variables in order to verify the robustness of this study.

The emotional response to an advertisement in a lab environment may not be the same as in a real environment, where consumers may discuss ads or products with the people around them (both consciously and unconsciously) while coming to a buying decision. The lab environment may control and stimulate emotional responses differently from watching an advertisement in a home setting. Laboratories equip and enable researchers to manipulate the environment and control potential threats to consumers' responses. Therefore, the results and findings of the study need to be treated with skepticism while measuring real market mechanisms and consumers' emotional behaviors. Sometimes, consumers feel that they are study objects during experiments (Tsai, 2010), and may feel differently than in a real market environment. They may not know how to rate and express their true feelings in a particular situation while being tested (Randall, 2009). Marketers and psychologists may use neuromarketing techniques to deal with such shortcomings and measure consumers' brain activity directly because it can measure the magnitude of commercial effectiveness in marketing (Sebastian, 2014). However, the validity of laboratory-based consumers' response versus the consumers' response in the real market environment continues to be questioned. 


\section{Conclusion}

The current study contributes to the understanding of how women, the most powerful consumers on earth (Tomlinson, 2007), could be emotionally affected by EAs. The resulting robustness notes that a better understanding of ACE combinations to develop EAs may generate the desired emotional response among Chinese women and influence their consumption behavior. The findings provide support to the arguments that emotional responses are predicted by the attention levels generated by EAs and how well the ACE combination is developed. The methods incorporated to map the antecedents to Chinese women's emotional responses generalize it to measure the response of consumers across different business marketing and advertising realms, and hence fuel the notions of Guerilla Marketing. This research has attempted to bridge the theoretical and practical research gaps. However, further research is needed to develop the insights into other niches in the business world by incorporating ACE combinations and engaging different target audiences with different demographic combinations. It generates a need for appropriate strategic planning from scholars and marketing professionals, execution of tactical strategies through emotional advertisements, and coordination of media to encapsulate the overall context.

\section{Appendix 1}

Scenario used in the psychological experiment.

You have a very good TV set with an elegant design, good picture quality, excellent sound, and sharp colors. It is $6: 16 \mathrm{pm}$ on a very pleasant day. You are sitting in front of a TV set and watching your favorite TV show. You have a very comfortable sofa seat and are relaxed with a peaceful surrounding environment. You just become deeply interested in the TV show. You feel that the room is silent except for the sound of the TV show. You don't want to turn down the volume of the TV show. Suddenly, TV show pauses for an advertisement. The advertisement features a celebrity but you are not that interested and start doing other things while watching. After the first advertisement, you think that the second advertisement is more interesting. You start watching the TV again with more interest. After few moments, you start feeling that the second advertisement is made just for you and you are thinking of buying the advertised product as well. After watching both of the advertisements, you wonder why the first advertisement did not hold your interest; and why the second advertisement convinced you to consider and buy the advertised product.

You are now given an opportunity to re-develop the first advertisement with your own choice of celebrity featuring, music, message, color, picture quality, and the kind of emotions to be shown by the celebrity endorser. What will you consider in order to re-develop the first advertisement which might effectively hold your interest; and convince you to buy and consume the product? Please choose your answer after developing the advertising combination and reading the attached questions. Your newly proposed advertising may be seriously considered by the advertising company, which may later incorporate your thoughts into the newly developed advertisement. 


\section{Appendix 2}

\section{Sound clips used in the psychological experiments}

\begin{tabular}{ll}
\hline 1. Man Laughing & 2. Truck Horn \\
3. Crowd Cheering & 4. Dog Bark \\
5. Cola Can Opening & 6. Ambulance Siren \\
7. Woman Scream & 8. Women Laughing \\
9. Shower & 10. Birds Chirping \\
11. Church Bells & 12. Steam \\
13. Telephone Ring & 14. Toilet Flush \\
\hline
\end{tabular}

\section{Abbreviations}

A: Appeal drivers; ACE: Appeal drivers, celebrity endorsement, and emotions; ALT: Associative learning theory; ARM: Advertising response model; C: Celebrity endorsement; E: Emotions; EA: Emotional advertisement; EAs: Emotional advertisements

\section{Acknowledgements}

We acknowledge the cooperation of Fujian Medical University, Fuzhou, China and the panel of professionals in helping the authors to conduct this research work. We also acknowledge the efforts of Dr. Katsiaryna Hurbik in proofreading early version of the article. We also acknowledge the support of David Ashal for his helpful comments in developing final version of this research work. On behalf of the authors, I would like to express our gratitude to the editors and anonymous reviewers for their critical comments and constructive suggestions.

\section{Authors' contributions}

SM: Conceptualization, conduct of psychological experiments, data gathering, data analysis, revisions, development and proofreading of the article. CL: Conceptualization, data gathering, data analysis, revisions, development and proofreading of article. MU: Data analysis, revisions, development and proofreading of the article. All authors read and approved the final manuscript.

\section{Funding}

This research work is supported by National Natural Science Foundation of China (Grant \# 71572039, Grant recipientChangbao Lu).

\section{Authors' information}

Salman Majeed, PhD, is an instructor of Marketing Management. His teaching interests are in the field of emotional marketing, consumer behaviors, and tourism development. Currently he is affiliated with School of Economics and Management, Fuzhou University China for his research work.

Changbao Lu, PhD, is a professor of Marketing in the School of Economics and Management at the Fuzhou University, Fujian, China. His teaching interests are in the fields of emotions and psychology, advertisement development, and consumer behaviors management. Currently, his research interest focuses on medical tourism management, medical tourism marketing, and medical tourists' behaviors. He has published over 60 academic articles and 3 books. Muhammad Usman, MBA, is a researcher and a marketing professional. He is currently affiliated with Institute of Business Administration (IBA) University of the Punjab, Pakistan. He is also serving as a lead business manager in Nippon Paints Pakistan (Private) Limited. His professional responsibilities are to manage the marketing, advertising, and sales functions of the industrial and consumer paint coatings in corporate sections of Pakistan. His recent interests are in the development of new markets and policymaking along with his other primary responsibilities.

\section{Competing interests}

The authors declare that they have no competing interests.

\section{Publisher's Note}

Springer Nature remains neutral with regard to jurisdictional claims in published maps and institutional affiliations.

\section{Author details}

${ }^{1}$ School of Economics and Management, Fuzhou University, Fuzhou, Fujian 350002, People's Republic of China. ${ }^{2}$ School of Economics and Management, Fuzhou University, Fuzhou, Fujian 350002, People's Republic of China. ${ }^{3}$ Institute of Business Administration (IBA), Quaid-e-Azam campus, University of the Punjab, Lahore 54000, Pakistan. ${ }^{4}$ Nippon Paint Pakistan (Private) Limited, Lahore 54000, Pakistan. 
Received: 11 July 2017 Accepted: 2 October 2017

Published online: 31 October 2017

\section{References}

Agrawal, J., \& Kamakura, W. A. (1995). The economic worth of celebrity endorsers: An event study analysis. Journal of Marketing, 59, 56-62.

Alexandris, K., Dimitriadis, N., \& Markata, D. (2002). Can perceptions of service quality predict behavioral intentions? Exploratory study in the hotel sector in Greece. Managing Service Quality, 12(4), 224-231.

Ali, M., Park, K. (2016). The mediating role of an innovative culture in the relationship between absorptive capacity and technical and non-technical innovation. Journal of Business Research, 69(5), 1669-1675.

Ashe-Edmunds, S. (2012) (n.d.). Chron.com. Retrieved October 3, 2016, from Small Business. chron website: http:// smallbusiness.chron.com/appeal-men-vs-women-advertising-12425.html.

Atsmon, Y., Magni, M., Li, L., \& Liao, W. (2012). Meet the 2020 Chinese Consumer in McKinsey Quarterly. Retrieved July 23, 2017, from McKinsey \& Company. https://www.mckinsey.com/global-themes/asia-pacific/meet-the-chinese-consumer-of2020.

Ayanwale, A. B., Alimi, T., \& Ayanbimipe, M. A. (2005). The influence of advertising on consumer brand preference. Journal of Social Sciences, 10(1), 9-16.

Bagozzi, R. P., Gopinath, M., \& Nyer, P. U. (1999). The role of emotions in marketing. Journal of the Academy of Marketing Science, 27(2), 184-206.

Bakshi, S. (2012). Impact of gender on consumer purchase behavior. Abhinav, 1, 9, 1-8.

Bijmolt, T. H., Claassen, W., \& Brus, B. (1998). Children are understanding of TV advertising: Effect of age, gender, and parental influence. Journal of Consumer Policy, 21, 171-194.

Bindu, M. H., Gupta, P., \& Tiwary, U. S. (2007). Cognitive Model - Based Emotion Recognition From. IEEE Symposium on Computational Intelligence in Images and Signal Processing (pp. 351-356). CIISP.

Biswas, S., Hussain, M., \& O'Donnell, K. (2009). Celebrity endorsements in advertisements and consumer perceptions: A crosscultural study. Journal of Global Marketing, 22, 121-137.

Boiger, M., \& Mesquita, B. (2012). The construction of emotion in interactions, relationships, and cultures. Emotion Review, 4(3), 221-229.

Brodie, R. J., llic, A., Juric, B., \& Hollebeek, L. (2011). Consumer engagement in a virtual brand community: An exploratory analysis. Journal of Business Research, 66(1), 105-114.

Brody, L. R. (1997). Gender and emotion: Beyond stereotypes. Journal of Social Issues, 53(2), 369-394.

Buksa, I., \& Mitsis, A. (2011). Generation Y's athlete role model perceptions on PWOM behavior. Young Consumers: Insight and Ideas for Responsible Marketers, 12(4), 337-347.

Bush, A. J., Martin, C. A., \& Bush, V. D. (2004). Sports celebrity influence on the Behavioral intentions of generation Y. Journal of Advertising, 108-118.

Cacioppo, J. T., \& Petty, R. E. (1989). The elaboration likelihood model: The role of affect and affect-laden information processing in persuasion. In P. Cafferata \& A. Tybout (Eds.), Cognitive and affective responses to advertising (pp. 69-89). Toronto: Lexington Books.

Chan, K. (2010). Youth and consumption. Hong Kong: City University of Hong Kong Press.

Choi, S. M., \& Rifon, N. J. (2007). Who is the celebrity in advertising? Understanding dimensions of celebrity images. Journal of Popular Culture, 40(2), 304-325.

Chu, S.-C. (2011). Determinants of consumer engagement in electronic word-of-mouth (eWOM) in social networking sites, International Journal of Advertising, 30(1), 47-75.

Coley, A., \& Burgess, B. (2003). Gender differences in cognitive and affective impulse buying. Journal of Fashion Marketing and Management, 7(3), 282-295.

Cotte, J., \& Ritchie, R. (2005). Advertisers' theories of consumers: Why use negative emotions to sell? Advances in Consumer Research, 32, 24-31.

Daneshvary, R., \& Schwer, K. R. (2000). The association endorsement and consumers' intention to purchase. Journal of Consumer Marketing, 17(3), 203-213.

Dittmar, H., Long, K., \& Meek, R. (2004). Buying on the internet: Gender differences in on-line and conventional buying motivations. Journal of Sex Roles, 50, 5-6.

Doherty, W. R., Orimoto, L., \& Singelis, T. M. (1995). Emotional contagion gender and occupational differences. Psychology of Women Quarterly, 19(3), 355-371.

Donges, U.-S., Kersting, A., \& Suslow, T. (2012). Women's greater ability to perceive happy facial emotion automatically: Gender differences in affective priming. PLOSone, 7(7), e41745.

Ekman, P. (1992). Facial expression of emotion: New findings new questions. Psychological Science, 3(1), 34-38.

Ekman, P. (2007). Emotions revealed: Recognizing faces and feelings to improve communication and emotional life. NY: OWL Books.

Engerror. (2013, May 24). Top 50 Popular Hollywood Actors and Actresses. Retrieved November 16, 2016, from IMBD: http:// www.imdb.com/list//s053501318/

Erdogan, B. Z., Baker, M. J., \& Tagg, S. (2001). Selecting celebrity endorsers: The practitioner's perspective. Journal of Advertising Research, 41, 39-48.

Falk, R. F., \& Miller, N. B. (1992). A primer on soft modeling. Akron: Univ. Akron Press.

Fischer, A. H., Rodriguez Mosquera, P. M., van Vianen, A. E. M., \& Manstead, A. S. R. (2004). Gender and cultural differences in emotion. Emotion, 4(1), 87-94.

Fisher, R. J., \& Dube, L. (2005). Gender differences in responses to emotional advertising: A social Desireability perspective. Journal of Consumer Research, 31(4), 850-858.

Foo, M.-D. (2011). Emotions and Entrepreneurial Opportunity Evaluation. Entrepreneurship Theory and Practice, 35(2), 375-393.

Gaines, C. (2016). The 20 most popular athletes in the world. Retrieved November 16, 2016, from Business Insider. http://www. businessinsider.com/most-famous-athletes-2016-5/\#no-11-gareth-bale-10 
Gharibi, S., Danesh, S. Y., \& Shahrodi, K. (2012). Explain the effectiveness of advertising using the AIDA model. Interdisciplinary Journal of Contemporary Research in Business, 4(2), 926-940.

Giele, F. (2009). Chinese Consumer Behaviour. Retrieved June 30, 2017, from Fransgiele: http://www.fransgiele.be/freematerial/ 2009chineseconsumerbehaviour.pdf

Guillaume, C., Geoffroy, A., Samet, B., Petra, V., \& Daniel, K. (2010). Advertisement makes you buy things you do not need! It manipulates you! Prague: CULS.

Hackley, C. (2005). Advertising and promotion: Communicating brands. London: Sage.

Hair, J. F., Anderson, R. E., Tatham, R. L., \& Black, W. (1998). Multivariate Data Analysis (5th ed.). Upper Saddle River, New Jersey: Prentice-Hall International Inc.

Hair, J.F., Jr., Hult, G.T.M., Ringle, C., \& Sarstedt, M. (2013).A primer on partial least squares structural equation modeling (PLSSEM). London: SAGE Publication Inc.

Hakimi, B. Y., Abedniya, A., \& Zaeim, M. N. (2011). Investigate the impact of celebrity endorsement on brand images. European Journal of Scientific Research, 58(1), 116-132.

Hakkak, M., Vahdati, H., \& Sharifinasab, A. (2016). Investigate the role of customer attitude in the process of emotional marketing impact on savings and life insurance buy intention (case study: Iran Insurance Agency in Ahvaz City). International Business Management, 10(10), 1799-1808.

Hambrick, M. E., \& Mahoney, T. Q. (2011). It's incredible-trust me': Exploring the role of celebrity athletes as marketers in online social networks. International Journal of Sports Management and Marketing, 10(3/4), 161-179.

Heath, R. (2007). Reinforcement and low processing. In G. J. Tellis \& T. Ambler (Eds.), The sage handbook of advertising (pp. 89-104). London: Sage.

Heath, R., Brandt, D., \& Nairn, A. (2006). Brand relationships: Strengthened by emotion, weakened by attention. Journal of Advertising Research, 46, 410-419.

Henseler, J., Ringle, C. M., \& Sarstedt, M. (2015). A new criterion for assessing discriminant validity in variance-based structural equation modeling. Journal of the Academy of Marketing Science, 43(1), 1-21.

Hollis, N. (2010). Millward Brown. Retrieved October 28, 2016, from A Millward Brown website: http://www.wpp.com/ / media/sharedwpp/readingroom/advertising/millward_brown_emotion_in_advertising.pdf

Holmberg, J., \& Ohenfeldt, R. (2010, May 24). The female fashion consumer behaviour. Female Fashion Consumer Behaviour Publication. Gothenburg: University Press.

Iordan, A. D., Dolcos, S., Denkova, E., \& Dolcos, F. (2013). Sex differences in the response to emotional distraction: An eventrelated fMRI investigation. Cognitive, Affective, \& Behavioral Neuroscience, 13(1), 116-134.

Jordan, P. W. (2001). Pleasure with products: The new human factors. In K. Baumann \& B. Thomas (Eds.), User interface Design for Electronic Appliances (pp. 303-328). Bristol: Taylor \& Francis.

Kaputa, C. (2009). The female brand. London: Davies-Black.

Kashyap, A. (2013). Branding and Marketing Strategies: Role of Human Emotions. International Journal of Innovation Research and Studies, 2(9), 337-342.

Khan, S., \& Nasr, M. (2011). Impact of lifestyle of Pakistani women on their buying behavior. International Review of Business Research Papers, 7(2), 292-309.

Khuong, M. N., \& Tram, V. N. (2015). The effects of emotional marketing on consumer product perception, brand awareness and purchase decision-A study in ho chi Minh City, Vietnam. Journal of Economics, Business and Management, 3(5), 524-530.

Kidwell, B., \& Hasford, J. (2014). Emotional ability and NonVerbal communication. Psychology and Marketing, 31(7), 526-538.

King, H. (2016). Social-EmotionalLearning: Setting children up for success by teaching them how to recognize and manage their emotions. Toronto: Ontario Institute for Studies in Education of the University of Toronto.

Klaus, N., \& Bailey, A. A. (2000). "Celebrity endorsements: an examination of gender and consumers' attitudes". American Journal of Business, 23(2), 53-61.

Knerl, L. (2010). Wisebread. Retrieved November 2, 2016, from 31 exceptional strategies for marketing to todays women: https:/www. americanexpress.com/en-us/business/trends-and-insights/articles/31-exceptional-strategies-for-marketing-to-todays-woman-1/.

Kotler, P., \& Armstrong, G. (2016). Principles of marketing (Global ed.) Prentice Hall.

Kumar, D. P., \& Raju, K. V. (2013). The role of advertising in consumer decision making. IOSR Journal of Business and Management, 14(4), 37-45

LaTour, M. S., Snipes, R. L., \& Bliss, S. J. (1996). Don't be afraid to use fear appeals: An experimental study. Journal of Advertising Research, 36, 59-68.

Lee, G. (2012). Modeling consumers' co-creation in tourism innovation. Philadelphia: Temple University.

Levinson, J. C. (2014). Guerrilla Marketing: Secrets for Making Big Profits from Your Small Business (3rdEdition ed.). NY-Boston: Houghton Mifflin Company.

Lewis, C., Fretwell, C., \& Ryan, J. (2012). An empirical study of emotional response to sounds in advertising. American Journal of Management, 12(1), 80-91.

Li, J., \& Su, C. (2007). How face influences consumption: A comparative study of American and Chinese consumers. International Journal of Market Research, 49(2), 237-256.

Lichtlé, M. (2007). The effect of an advertisement's colour on emotions evoked by attitude towards the ad: The moderating role of the optimal stimulation level. International Journal of Advertising, 26, 37-62.

Lii, Y. S., \& Sy, E. (2009). Internet differential pricing: Effects on consumer price perception, emotions, and behavioral responses. Computer in Human Behavior, 25(3), 770-777.

Lwin, M., \& Phau, I. (2013). Effective advertising appeals for websites of small boutique hotels. Journal of Research in interactive Marketing, 7(1), 18-32.

Lynn, M. (2011). Segmenting and targeting your market: Strategies and limitations [Electronic version]. Retrieved January 09, 2017, from Cornell University, School of Hospitality Administration site: http://scholarship.sha.cornell.edu/articles/243

Marie, E. (2009) (n.d.). Chron.Com. Retrieved October 20, 2016, from Small Business.chron website:http://smallbusiness.chron. com/difference-rational-emotional-marketing-23661.html

Martin, C. A., \& Bush, A. J. (2000). Do role models influence teenagers' purchase intentions and behavior? Journal of Consumer Marketing, 17(5), 441-454. 
Martin, N., \& Morich, K. (2011). Unconscious mental processes in consumer choice: Toward a new model of consumer behavior. Journal of Brand Management, 8(7)483-505.

Martin-Santana, J. D., Muela-Molina, C., Reinares-Lara, E., \& Rodriguez-Guerra, M. (2015). Effectiveness of radio spokesperson's gender, vocal pitch and accent and the use of music in radio advertising. Business Review Quarterly, 18(3), 143-160.

Matthes, J., Wonneberger, A., \& Schmuck, D. (2014). Consumers' green involvement and the persuasive effects of emotional versus functional ads. Journal of Business Research, 67, 1885-1893.

Mayer, J. D., Salovey, P., \& Caruso, D. R. (2008). Emotional intelligence: New ability or eclectic traits. American Psychologist, 63(6), 503-517.

McCracken, G. (1989), "Who is the celebrity endorser? Cultural foundations of the endorsement process". Journal of Consumer Research, 16(3), 310-321.

McLeod, S.A. (2009). Independent, Dependent and Extraneous Variables. Retrieved from www.simplypsychology.org/variables. html. Accessed 21 Oct 2016.

Mehta, A. (1994). How advertising response Modeling (ARM) can increase ad effectiveness. Journal of Advertising Research, 34(3), 62-74.

Miciak, A. R., \& Shanklin, W. L. (1994). Choosing celebrity endorsers. Marketing Management, 3(3), 51-59.

Mogaji, E. (2015). Reflecting a diversified country: A content analysis of newspaper advertisements in great Britain. Marketing Intelligence \& Planning, 33, 908-926.

Muehling, D. D., Sprott, D. E., \& Sultan, A. J. (2014). Exploring the boundaries of nostalgic advertising effects: A consideration of childhood brand exposure and attachment on consumers' responses to nostalgia-themed advertisements. Journal of Advertising, 43(1), 73-84.

Niazi, G., Siddiqui, J., Shah, B., \& Hunjra, A. (2012). Effective advertising and its influence on consumer buying behavior. Information Management and Business Review, 4(3), 114-119.

O' Shaughnessy, J., \& O' Shaughnessy, N. J. (2003). The marketing power of emotion. New York: NY: Oxford University Press.

O'Mahony, S., \& Meenaghan, T. (1998). The impact of celebrity endorsements on consumers. Irish Marketing Review., $10(2), 15$.

Oatley, K., \& Johnson-Laird, P. N. (2014). Cognitive approaches to emotions. Trends in Cognitive Sciences, 18(3), $134-140$.

Oliver, M. B., Weaver III, J. B., \& Sargent, S. L. (2000). An examination of factors related to sex differences in enjoyment of sad films. Journal of Broadcasting and Electronic Media, 44(2), 282-300.

Orth, H. R., Malkewitz, K., \& Bee, C. (2012). Gender and personality drivers of consumer mixed emotional response to advertising. Journal of Current Issues \& Research in Advertising, 32, 69-80.

Park, W., \& Young, M. S. (1986). Consumer response to television commercials: The impact of involvement and background music on brand attitude formation. Journal of Marketing Research, 23(1), 11-24.

Patel, P. C. (2009). Impact of celebrity endorsement on brand acceptance. Journal of consumer Behavior, 4, 36-45.

Percy, L. (2003). Understanding the role of emotion in advertising. Copenhagen: Department of Marketing, Copenhagen Business School.

Percy, L., \& Rosenbaum-Elliott, R. (2012). Strategic advertising management. Oxford: Oxford University Press.

Plutchik, R. (1997). The circumplex as a general model of the structure of emotions and personality. In R. Plutchik \& H. R. Conte (Eds.), Circumplex model of personality and emotions (pp. 17-45). Washington, DC: American Psychological Association.

Poels, K., \& Dewitte, S. (2006). How to capture the heart? Reviewing 20 years of emotion measurement in advertising. Journal of Advertising Research, 46, 18-37.

Pringle, H. (2004). Celebrity sells. Chichester: Wiley.

Pringle, H., \& Binet, L. (2005). How marketers can use celebrities to sell more effectively. Journal of Consumer Behaviour, 4(3), $201-214$.

Rai, N. (2013). Impact of advertising on consumer behavior and attitude with reference to consumer durables. International Journal of Management Research and Business Strategy, 2(2), 2-8.

Randall, K. (2009). Neuromarketing hope and hype: 5 Brands conducting brain research. Fast Company.

Randhir, R., Latasha, K., Tooraiven, P., \& Monishan, B. (2016). Analyzing the impact of sensory marketing on consumers: A case study of KFC. Journal of US-China Public Administration, 13(4), 278-292.

Rhoton, C. E. (2014). A Multiple Regression And Concurrent Validity Analysis Of High School Seniors' Social Competence, Ability To Manage Emotions, And Their Time Spent On Facebook. Virginia: Liberty University.

Richins, M. L. (1997). Measuring emotions in the consumption experience. Journal of Consumer Research, 24, $127-146$.

Ringle, C. M., Wende, S., \& Becker, J. M. (2015). SmartPLS 3. Bönningstedt: SmartPLS Gmbh.

Roos, J. M. (2014). Personal marketing appeals: How personality dimensions influence feelings toward emotional images. International Journal of Economics Practices and Theories, 4(5), 526-533.

Roozen, I. (2013). The impact of emotional appeal and the media context on the effectiveness of commercials for not-forprofit and for-profit brands. Journal of Marketing Communications, 19(3), 198-214.

Roozen, I., \& Claeyes, C. (2009). Do emotional appeal and media-context influence the effectiveness of TV commercials for profit and non-profit brands? HUB Research Papers, 3, 2-17.

Rytel, T. (2010). Emotional marketing concept: The new marketing shift in the post modern era. Business: Theory and Practice, 11(1), 30-38.

Saad, F. (2011). Brand loyalty through emotional advertisement. Journal of Marketing Philosophy \& Practice, 1(1), 10-13.

Sebastian, V. (2014). Neuromarketing and evaluation of cognitive and emotional responses of consumers to marketing stimuli. Procedia- Social and Behavioral Sciences, 127, 753-757.

Seno, D., \& Lukas, B. A. (2007). The equity effect of product endorsement by celebrities: A conceptual framework from a cobranding perspective. European Journal of Marketing, 41(1/2), 121-134.

Shevde, N. (2008). All's fair in love and cream:A cultural case study of Fair \& Lovely in India. Advertising and Society Review, $9(2), 1-9$.

Shiau, W. L., \& Luo, M. M. (2012). Factors affecting online group buying intention and satisfaction: A social exchange theory perspective. Computers in Human Behavior, 28(6), 2431-2444.

Sliburyte, L. (2009). How celebrities can be used in advertising to the best advantage? World Academy of Science, Engineering and Technology, 58, 934-939. 
Small, D. A., \& Verrochi, N. M. (2009). The face of need: Facial emotion expression on charity advertisements. Journal of Marketing Research, 46(6), 777-787.

Smith, A. K., Bolton, R. N., \& Wagner, J. (1999). A model of customer satisfaction with service encounters involving failure and recovery. Journal of Marketing Research, 36(3), 356-372.

Solomon, M. (2002). Consumer behaviour: Buying, having, and being (5th ed.). New Jersey: Prentice Hall.

Solomon, S. J., \& Bendickson, J. (2016). Generating Press, bold ideas, and stubbornness: The impact of celebrity CEOS. Journal of Business Strategies, 33(1), 67-93.

Souro, J. (2010,). What Is A Representative Sample Size For A Survey? Retrieved November 18, 2016, from Measuring Usability, Customer Experience and Statistics: http://www.measuringu.com/survey-sample-size.php

Stern, B. B. (1999). Gender and multicultural issues in advertising: Stages on the research highway. Journal of Advertising, 28(3), $1-9$.

Stoeckel, L. E., Cox, J. E., Cook, E. W., \& Weller, R. E. (2007). Motivational state modulates hedonic value of food images differently in men and women. Appetite, 48, 139-144.

Swani, K., Brown, B. P., \& Milne, G. R. (2014). Should tweets differ for B2B and B2C? An analysis of fortune 500 companies' twitter communications. Industrial Marketing Management, 43(5), 873-881.

Tehseem, T., \& Kalsoom, U. (2015). Exploring the veiled ideology in cosmetics adverts: A feminist perspective. European Journal of Research in Social Sciences, 3(2), 81-98.

Thwaites, D., Lowe, B., Monkhouse, L. L., \& Barnes, B. R. (2012). The impact of negative publicity on celebrity ad endorsements. Psychology \& Marketing, 29(9), 663-673.

Till, B. D., \& Busler, M. (2000). The match-up hypothesis: Physical attractiveness, expertise, and the role of fit on brand attitude, purchase intent, and brand beliefs. Journal of Advertising, 29(3), 1-14.

Tomey, K. (2014). Using colour as an indicator of mood induced by destination advertisement music. In International student conference in tourism research (ISCONTOUR)T 2014. Krems: IMC-University of Applied Sciences Krems and Salzburg University of Applied Sciences.

Tomlinson, G. (2007). A Book Report on Marketing to Women (How to Increase Your Share of the World's Largest Market). Retrieved November 04, 2016, from Gary Tomlinson Website: http://www.gary-tomlinson.com

Tsai, J. (2010). Are you smarter than a neuromarketer. Customer Relationship Management, 14, 19-20.

Turley, L. W., \& Kelley, S. W. (1997). A comparison of advertising content: Business to business versus consumer services, Journal of Advertising, 26, 39-48.

Vigil, J. M. (2009). A socio-relational framework of sex differences in the expression of emotion. Behavioral and Brain Sciences, $32,375-428$.

Wagner, K. (2013). "Looks great, feels amazing" The tactile dimension of packaging. In L. Hansson, U. Holmberg, \& H. Brembeck (Eds.), Making Sense of Consumption: Selections from the 2nd Nordic Conference on Consumer Research 2012. (pp. 139-152). Gothenburg, Sweden.

Wang, J. S., Cheng, Y. F., \& Chu, Y.-L. (2013). Effect of celebrity endorsements on consumer purchase intentions: Advertising effect and advertising appeal as mediators. Human Factors and Engonommics in Manufacturing \& Service Industries, 23(5), $357-367$.

Wei, P. S., \& Lu, H. P. (2013). An examination of the celebrity endorsements and online customer reviews influence female consumers' shopping behavio. Computers in Human Behavior, 29, 193-201.

Wijaya, B. S. (2012). The development of hierarchy of effects model in advertising. International Research Journal of Business Studies, 5(1), 73-85.

Williams, K. C. (2011). Improving fear appeal ethics. Journal of Academic and Business Ethics, 5, 1-24.

Witte, K. (1994). Fear control and danger control: A test of the extended parallel process model (EPPM). Communication Monographs, 61, 113-134.

Zammuner, V. L. (1998). Concepts of emotion: 'Emotionness', and dimensional ratings of Italian. Cognition and Emotion, 12, $243-272$.

Zeitlin, D. M., \& Westwood, R. A. (1986). Measuring emotional response. Journal of Advertising Research, 26, 34-44.

Zhou, L., \& Whitla, P. (2013). How negative celebrity publicity influences consumer attitudes: The mediating role of moral reputation. Journal of Business Research, 66, 1013-1020.

Zipser, D., Chen, Y., \& Gong, F. (2016). Here comes the modern Chinese Consumer. Retrieved July 29, 2017, from McKinsey \& Company. https://www.mckinsey.com/industries/retail/our-insights/here-comes-the-modern-chinese-consumer.

Zulkifly, H. Z., \& Firdaus, N. (2014). Persuasion and the online consumers: Investigating copywriting strategies in native advertisements. International Journal of Social and Humanity, 4(6), 430-434.

\section{Submit your manuscript to a SpringerOpen ${ }^{\circ}$ journal and benefit from:}

- Convenient online submission

- Rigorous peer review

- Open access: articles freely available online

High visibility within the field

- Retaining the copyright to your article

Submit your next manuscript at $\boldsymbol{\nabla}$ springeropen.com 